\title{
Precautionary Suspension in the Workplace and the Employees' Right to be Heard
}

\author{
Jane Tsakane Baloyi-Ngobeni \\ Kola O. Odeku \\ Faculty of Management and Law, School of Law, \\ University of Limpopo, South Africa \\ E-mail:kooacademics@gmail.com
}

\author{
Doi:10.5901/mjss.2013.v4n14p797
}

\begin{abstract}
Adherence to disciplinary procedures to ensure fairness is a reality in modern times where employees and labour organisations are more cautious of their rights than in the past. Times have changed to such an extent that almost each and every labour sector have people whose concern is to see to it that employees are not unnecessarily treated unfairly. And that those employees who do not even know what their rights are to be sensitised, in order to protect them against employers who take advantage of them. This paper examines the rights of employees in the public sector regarding the right to be heard before precautionary suspension can be implemented. The principle of audi alteram partem which simply means that (one must hear the other side before making a decision) should play a very critical role in determining whether or not to suspend before a disciplinary hearing commences.
\end{abstract}

Keywords: Disciplinary procedures, Representation, Interference, Prejudice, Fair Hearing.

\section{Introduction}

In South Africa, there have been divergent opinions on whether an employee who was charged with misconduct should be placed on an immediate suspension without being given the right or opportunity to be heard. It is against the background of this that this paper examines the right of an employee to be heard before the employer can place the employee on precautionary suspension (Rheeder, 2013). Precautionary suspension (herein after referred to as 'Suspension') is defined in clause 7.2.7(2) of the Public Service Disciplinary Code and Procedure, Resolution 1 of 2003 as a measure through which the employer may suspend the employee on full pay if the employee is alleged to have committed a serious offence and the employer believes that the presence of such employee at the workplace might jeopardise any investigation into the alleged misconduct or endanger the wellbeing or safety of any person or state property.

Section 186(2)(b) of the Labour Relations Act 66 of 1995 (LRA) provides that "unfair labour practice means any unfair act or omission that arises between an employer and an employee involving (b) the unfair suspension of an employee or any other unfair disciplinary action short of dismissal in respect of an employee."

Chapter 7 of the Senior Management Service Handbook, 2003 (SMS Handbook) which deals with Misconduct and Incapacity of the Senior Management Service (SMS) employees defines precautionary suspension in clause 2.7(2) as a suspension upon the employee by the employer, if there are allegations that the employee committed a serious offence, and the employer believes that the presence of the employee at the workplace might jeopardise any investigation into the alleged misconduct, or endanger the wellbeing or safety of any person or state property. Precautionary suspension is therefore according to the SMS Handbook an action where the employer suspends an employee where there is reason to believe that the employee may interfere with witnesses or evidential material or to even commit further misconducts.

According to Grogan (2007), "suspension is a term used in the employment context to describe situations in which an employer declines to accept an employee's services because the employer believes that the presence of the employee would jeopardise any investigation into the alleged misconduct or endanger the wellbeing or safety services but does not terminate the contract."

If the employer unilaterally changed the terms of employment without notifying the employee, the employee might inadvertently contravene the terms without knowing. In this situation, the employer may not sustain suspension because the act amounted to unfair labour practice (Duffy and Hostetler, 2013). However this does not mean that the relationship 
between the parties is so frozen that the employer cannot change the working practices, but that can only be done if the changes do not alter the employee's contractual rights (Neville and Hayes, 2009). To avoid this type of situation, it is important that the employer should engage with the employees prior to any variations or changes in the terms of the employment contract.

Law is not static but dynamic (Kabir, 2013), often; case law and different legislations passed do have substantial effect and impact on the law. This is evident in the recent decision of the Labour Appeal Court of South Africa (LAC) In the case of Member of the Executive Council for Education, North West Provincial Government and Errol Randal Gradwell, (hereinafter referred to as the Gradwell's case) (Unreported Case number JA 58/10, Labour Appeal Court, Johannesburg, judgment delivered on the 25/04/2012), where the court held that the right to a hearing prior to a precautionary suspension arose not from the Constitution of the Republic of South Africa, 1996, (hereinafter referred to as the Constitution), but from the LRA. According to the judgment, it is an unfair labour practice if a person is not given the right to be heard before he was placed on precautionary suspension. This will be flagrant violation of provision of sections $186(2)(b)$ of the LRA.

\section{Objective}

The objective of this paper is to examine whether an employee who would be put through disciplinary processes based on the allegation of misconduct has a right to be heard before a decision is reached to suspend him or not pending investigations and during disciplinary hearing. The paper considers the importance of fair labour practice that requires that the employee should be given an opportunity to be heard on whether there should be suspension or not. The paper also looks at the importance of preparatory procedures which must take place before an employee can be placed on precautionary suspension. These processes are important because they will eventually determine whether an employee should be suspended or not.

\section{Conceptual Clarifications}

The right to be heard before suspension is not a formally defined process in which employers and employees are guided on what to do, but case law has developed this concept to an extent that it has been declared unprocedural not to follow this process. In the case of POPCRU obo Masemola \& others v Minister of Correctional Services [2009] JOL 24694 (LC), the court held that it is improper to suspend an employee without affording them an opportunity to provide reasons as to why a precautionary suspension should not be put into operation.

In the Gradwell's case, on paragraph 45 of the judgment the court said that: "The right to a hearing prior to precautionary suspension arises therefore not from the Constitution or as an implied term of the contract of employment, but is a right located within the provisions of the LRA, the correlative of the duty on employers not to subject employees to unfair labour practices. That being the case, the right is a statutory right for which statutory remedies have been provided together with statutory mechanisms for resolving disputes in regard to those rights."

The Constitution protects the rights of each and every individual in South Africa, including the rights of individuals in labour matters. Section 23 of the Constitution provides that everyone has the right to fair labour practices. The Constitution does not categorically prescribe as to what fair labour practices are, and which ones are the unfair labour practices, but section 186(2)(b) of the LRA classifies an unfair suspension of an employee as an unfair labour practice.

To constitute an unfair labour practice, the act or omission complained of must be between an employee and the employer. Le Roux (2012) defines unfair labour practice as guaranteed in the Constitution as an unusual constitutional right that is primarily only concerned with the exercise of private rather than public power.

Biggs and van der Walt (2011) quoted what the court said in the case of NEHAWU v University of Cape Town (2003) 24 ILJ 95 (CC) in order to show how the Constitution impacts on the employment relationship between the employer and the employee when balancing the issue of fair labour practices. The following passage was quoted from the judgment where Ncgobo $\mathrm{J}$ in NEHAWU's case assessed the fairness component of the right to fair labour practices, which he defined in terms of a balancing or accommodation of often competing interests:

"In my view the focus of section 23 is, broadly speaking, the relationship between the worker and the employer and the continuation of that relationship on terms that are fair to both. In giving content to that right, it is important to bear in mind the tension between the interests of the workers and the interests of the employers that is inherent in labour relations. Care must therefore be taken to accommodate, where possible, these interests so as to arrive at the balance required by the concept of fair labour practices. It is in this context that LRA must be construed." 
It is against the backdrop of this misapplication of precautionary suspension that this paper seeks to sensitise employers about the rights which employees who are to be suspended have, so that they can follow right procedures for the suspensions not to be declared unfair in terms of provisions of section 186(2)(b) of the LRA.

It is also important for employees who are faced with suspensions by their employers to be aware of the procedures that have to be followed so that they can also be able to exercise the rights which are available to them in terms of the law.

Employers should note that if an employee is given the right to be heard before suspension, the possibility is that after having considered the reasons which the employee would have advanced, it will then be easier to determine whether it would be necessary to suspend the employee or not. This was clearly illustrated in the case of Marcus v Minister of Correctional Services \& others [2005] 2 BLLR 215 (SE), where on page 217 of the judgment, a paragraph was quoted from the affidavit of one Malatsi, who held the position of Director Departmental Investigations Unit (DIU) which reads as follows:

"I might at this stage point out that the investigation into the allegations involving misconduct and maladministration is well advanced. If the Applicant's suspension is in fact reinstated (sic) I anticipatethat the Department will in all likelihood require no more than a further week to finalise its investigation."

The respondents failed to furnish further particulars to support the allegations against the applicant, and as such the applicant was not in a position to make a proper representation as to why should he not be suspended as he did not have full particulars relating to the allegations against him.

It is therefore incumbent on the employee to show that when given an opportunity to make representations to the employer on the issue of suspension, the employee must show and convince the employer that being present in the workplace would not prejudice the investigations.

For one to be able to know as to whether the presence will prejudice the investigations, one must be given full details of particulars of the allegations concerned. The employers must know that they can only suspend if there is a clear apprehension that the employee will interfere with investigations, and that must be supported by facts (Conradie and Deacon, 2009).

\section{The Right to be Heard before Suspension}

Section 186(2) (b) of the LRA defines an unfair labour practice as the unfair suspension of an employee or any other unfair disciplinary action short of dismissal. Gaibie (2012) identified three criteria which have been set down in the case of Mogothle v Premier of the North-West Province and Another (2009] 4 BLLR 331 (LC), which must be satisfied in order for the suspension to be substantively and procedurally fair, and they are the following:

1. The employer must have a justifiable reason to believe, prima facie at least, that the employee has engaged in serious misconduct;

2. There is some objectively justifiable reason to deny the employee access to the workplace based on the integrity of any pending investigation into the alleged misconduct, or some other relevant factor that would place the investigation or the interests of the affected parties in jeopardy;

3. The employee is given the opportunity to state a case or to be heard before any final decision to suspend is made.

The principles above which were laid down in the Mogothle's case are in line with the provisions of chapter 7 of the Disciplinary Code and Procedures for SMS members in part 2.7 (2) of the SMS handbook. However many employers seem not to understand that the employee should not be prevented from coming to work even if there are certain allegations against the employee. It is only if the presence of the employee will interfere with investigations or pose a threat, as was noted by the court in the Mogothle's case, that the employee can be prevented to enter the workplace and work.

The employer needs to allow the employee to satisfy it that the right to be heard is significant and fair labour practice. Biggs and Van der Walt (2011) observe that little or no guidance has been given by the courts regarding the scope of an enquiry afforded to an employee prior to preventative suspension, and each case has to be judged according to its merits. Although a formal enquiry is not required prior to suspension pending a disciplinary enquiry, the audi alteram partem principle should be observed and applied (Biggs and Van der Walt, 2011).

A preventative suspension may also be unfair in instances where there is a right to be heard prior to the suspension, but that being not observed by the employer. Although the Commission for Conciliation, Mediation and 
Arbitration (CCMA) and a Bargaining Council have the powers to decide on the unfairness of the suspension in terms of provisions of section 186(2)(b) of the LRA, section 158(1)(a) of the LRA gives the Labour Court the power to grant urgent interim relief in respect of disputes that must ultimately be determined by arbitration (McGregor and Budeli, 2010). It is worthy to point out that the mere fact that an investigation will be held is not enough reason for the suspension of the employee. It must be proven that the employee's presence may prejudice the investigation.

Section 186(2)(b) of the LRA simply states that it is an unfair labour practice to suspend an employee based on unfair reasons. Pursuant to this, suspension with full pay pending a disciplinary hearing will not be unfair if the employer has a reasonable apprehension that a legitimate business interest would be harmed by the employee's continued presence in the workplace. The court, in the case of SAPO Ltd v Jansen van Vuuren NO \& others [2008] 8 BLLR 798 (LC) outlined what the employers should do in order for their actions not to be labelled as unfair labour practice thus "a suspension must be based on substantive reasons and a fair procedure needs to be followed: There is a need to send a message to employers that they should refrain from hastily resorting to suspending employees when there are no valid reasons to do so. Suspensions have a detrimental impact on the affected employee and may prejudice his or her reputation, advancement, job security and fulfilment. It is therefore necessary that suspensions are based on substantive reasons and fair procedures are followed prior to suspending an employee. In other words, unless circumstances dictate otherwise, the employer should offer an employee an opportunity to be heard before placing him or her on suspension."

There are several decided cases which support the assertion that an employee must be given an opportunity to be heard before being placed on precautionary suspension. In the case of Ngwenya v Premier of Kwazulu-Natal [(2001] 8BLLR $924(\mathrm{LC})$ ), where the second precautionary suspension against the applicant was set aside and one of the reasons was that the applicant was not given an opportunity to be heard before he was suspended for the second time.

The issue in the case of Baloyi v Department of Communications \& others [(2009] JOL 24694) was whether the audi alteram partem rule, which when loosely translated means that each party to a dispute must be given an opportunity to be heard, was adhered to. The applicant was given a notice of intention to suspend her by the Director General at a very short notice, and when she sought clarity on the allegations against her to be able to respond to the notice, she was then suspended before she could respond. The court held in this case that in terms of the audi alteram partem rule, an employee is before suspension entitled to a fair and reasonable opportunity to make representations before suspension as to why she should not be suspended. The applicant was in this case not afforded a proper opportunity to make representations.

Similarly, in the case of PSA obo Blose \& others/Department of education, Kwazulu-Natal [(2009] JOL 24420 (GPSSBC), the applicants were suspended on full pay for a period of more than two years without any disciplinary action being taken against them. The Bargaining Council (GPSSBC) set aside the precautionary suspensions as they were found to be procedurally unfair, because they were not given opportunity to make representations before they were suspended, and the disciplinary hearing was not held within a month or 60 (sixty) days as required by Resolution 1 of 2003.

\section{Suspension of Senior Managers in Local Government}

Department of Cooperative Governance and Traditional Affairs (COGTA) also adopted the Local Government Disciplinary Code and Procedures for Senior Managers, 2010, which is incorporated in the Municipal Systems Act 32 of 2000. Clauses 6 of Chapter 2 of these Regulations deal with precautionary suspensions and provides that:

"(2) Before a senior manager may be suspended, he or she must be given an opportunity to make written representation to the municipality council why he or she should not be suspended, within seven (7) days of being notified of the council's decision to suspend him or her.

(3) The municipal council must consider any representation submitted to it by the senior manager within seven (7) days.

(4) After having considered the matters set out in sub-regulation (1), as well as the senior manager's representations contemplated in sub-regulation (2), the municipal council may suspend the senior manager concerned.

(5) The municipal council must inform -

(a) the senior manager in writing of the reasons for his or her suspension on or before the date on which the senior manager is suspended; and

(b) the minister and the MEC responsible for local government in the province where such suspension has taken place, must be notified in writing of such suspension and the reasons for such within a period of seven(7) days after such suspension."

In accordance with these Regulations the senior manager in the municipality may be placed on precautionary suspension if it is alleged that the senior manager committed an act of misconduct, and if the municipal council has 
reason to believe that the continued presence of the senior manager may jeopardise any investigation, endanger the safety of any person or municipal property, bring instability in the municipality, interfere with potential witnesses or commit further acts of misconduct (LGCADP, 2010).

However, before a senior manager can be suspended, he must be given an opportunity to make a representation to the municipal council within seven (7) days to the municipal council as to why that member should not be suspended. The decision to suspend and the response must be considered by the municipal council within seven (7) days after receiving the representation. After considering the written representation and the municipal council decides to proceed with the suspension the senior manager must be informed in writing of the suspension on or before the date of the suspension.

In the case of Biyase v Sisonke District Municipality \& another [(2011] JOL 28131 (LC)), the applicant who was a senior manager of the Sisonke District Municipality was given notice of intention to suspend him by the municipality, and he was given only four days to respond to the notice. The applicant brought an urgent application in the Labour Court to challenge his suspension on the basis that the procedural steps that were to be followed before he was placed on precautionary suspension were not followed. The precautionary suspension was set aside by the Labour Court as the applicant was given only four days to respond to the notice of the municipal council to suspend him, instead of being given seven (7) days as required by Regulation 6 .

The court further remarked in this case that the Regulations impose obligations on municipalities with regard to procedural steps in disciplinary proceedings, and that they are bound by them.

The court observed in the Biyase's case that even though the applicant was given an opportunity to make representations, he is still suffering harm and his integrity and reputation have been sullied, because the applicant was just provided with the copy of the complaint without an explanation as to why he was suspended whereas Regulation 6 requires that he be suspended if there is reason to believe that his presence at the workplace may jeopardise investigations into the alleged misconduct, endanger the well-being or safety of any person or municipal property, be detrimental to stability in the municipality. The applicant could be suspended if there was reason to believe that he will interfere with potential witnesses, or commit further acts of misconduct.

The court also observed that an employee will normally be negatively affected by the suspension, as this may have serious personal and social consequences for the employee and that the right to work is linked to the right to dignity. This was clearly put in perspective in paragraph 31 of the Mogothle's judgement, where the following passage was quoted by the court:

"In so far as the substantive dimension of fair dealing in relation to suspension is concerned, Halton Cheadle has observed that suspension is the employment equivalent of arrest, with the consequence that an employee suffers palpable prejudice to reputation, advancement and fulfilment. On this basis, he suggests that employees should be suspended pending a disciplinary enquiry only in exceptional circumstances."

Smit \& Mpedi (2012) said the following on the effects of suspension on an employee:

"A right to be heard before being suspended pending disciplinary proceedings has been reconfirmed by the labour court... This is necessary, as suspension affects the integrity and dignity of the suspended person as well as his or her freedom to engage in productive work (whether the suspension is with or without pay)."

It was reiterated in the SAPO case that there is a need to send a message to employers that they should refrain from hastily resorting to suspending employees when there are no valid reasons to do so. In discouraging employers to impose precautionary suspensions unnecessarily, the court said that:

\begin{abstract}
"There is however, a need to send a message to employers that they should refrain hastily resorting to suspending employees when there are no valid reasons to do so. Suspensions have a detrimental impact on the affected employee and may prejudice his or her reputation, advancement, job security and fulfilment. It is therefore necessary that suspensions are based on substantive reasons and fair procedures are followed prior to suspending an employee. In other words, unless circumstances dictate otherwise, the employer should offer an employee an opportunity to be heard before placing him or her on suspension."
\end{abstract}

\title{
6. Situations Where Suspensions will be Sustained and Upheld
}

Where the employee has virtually unlimited authority over the subordinates and access to all the documentation in 
relation to misconduct and where it was found that the employee has been pressurised his subordinates to sign documents. In this situation, the continued presence at the workplace might jeopardise the process of investigation. Where an employee is given an ample time and an opportunity in line with the provisions of the regulations to make representation before he was suspended but failed to, the court will upheld the suspension.

Consequently, the justifiability of a suspension rests on the existence of a reason which, at face value causes a belief that the employee committed serious misconduct. A second line of enquiry is then necessary to deal with the justifiability in denying access to the workplace. The nature, likelihood and seriousness of the alleged misconduct would be the relevant considerations.

\section{Pitfalls and Interventions to Resolve Precautionary Suspensions in Public Service}

The Public Service Commission (PSC, 2011) was created in terms of provisions of section 196 of the Constitution. The duty of the PSC is to enhance excellence in governance within the Public Service by promoting a professional and ethical environment and saddling value to a public administration that is accountable, efficient and effective and that is archived by investigating, monitoring, evaluating, communication and reporting on public administration.

In June 2011 the PSC compiled a report on precautionary suspensions in the Public Service in South Arica. According to the report, 293 employees in the public service in different government departments were placed under precautionary suspension during the period 2008/2009, and a total amount of R15, 513978.84 was paid to those employees. The remuneration to 369 employees placed on precautionary suspension during the period 2009/2010 was more than R45 million according to the report. The report revealed that there was generally non-compliance with the time periods of instituting the disciplinary hearings after an employee has been placed on precautionary suspension. The reasons for non-compliance were stated as the unavailability of witnesses, representatives, interpreter, employee concerned, presiding officer and so on.

The report also showed that in the government departments in South Africa, except for the KwaZulu-Natal Department of Transport, most of them did not develop any guidelines to assist them in dealing with labour relations issues. The departments usually relied on Resolution 1 of 2003 which provides for a clear guideline on the procedures to be followed when an employee has been placed on precautionary suspension.

The report also identified lack of knowledge by most managers and labour relations officers in the government departments on issues of precautionary suspensions as one of the problems causing delays in the finalisation of these matters. The court has raised this pitfall and concern in the case of Heyneke v Umhlatuze Municipality (2010) 31 ILJ 2608 (LC) about the inefficiencies by personnel officials who are supposed to deal with issues of precautionary suspensions by saying that:

"Protracted leave or suspension on full pay pending investigations or disciplinary actions is a prevalent practice, especially in publicly funded entities. This practice is a sign of weak, indecisive management that cannot diagnose problems and find solutions efficiently. These inefficiencies impact on both taxpayers and shareholders alike, and not on the private pockets of the management of public organizations; consequently, the incentive to finalize investigations and disciplinary procedures is weak . This practice has to stop."

The PSC compiled another report dated 23 November 2011 on management of precautionary suspensions in the public service. The same findings were reported as the ones which were stated in the June 2011 report. The reports made the following recommendations as solutions to unfair suspensions and the inability by labour relations officers to handle precautionary suspensions:

i. The labour relation units must play an active role in keeping track of all cases of misconduct and ensure a consistent manner of reporting on the management of precautionary suspension.

ii. There must be a database of capable presiding officers and investigators internally within departments, and centrally through the Department of Public Service and Administration (DPSA) and offices of the premiers.

iii. There should be a requirement for departments to explain what measures departments take against managers who delay conclusion of disciplinary procedure and in the case of precautionary suspension of Senior Management (SMS) members, including heads of departments, extension of the 60 days period should only be made after consultation with the Minister for the Public Service and Administration (MPSA).

iv. Departments must before placing employees on precautionary suspension seriously consider transfers as an alternative to precautionary suspension.

v. Departmental policies must be developed which deals with precautionary suspensions, all employees must be 
trained on basic things like disciplinary procedures, because lack of understanding of disciplinary procedures results in low level of compliance with the management of discipline.

vi. There is a dire need to expedite investigations and finalisation of hearings of cases to avoid disappearance of witnesses and documents as well as improved service delivery in the Public Service.

vii. The departments need to improve on adherence to prescribed timeframes that will result in reduced costs relating to salaries of employees who are on precautionary suspensions for lengthy periods.

\title{
8. Remedies Available to Victims of Unfair Suspensions
}

The case of Booysen v The Minister of Safety \& Security and others (2011] 1 BLLR 83 (LAC)) is a clear case in which the applicant exhausted all the remedies that are available to an employee who felt aggrieved by the employer's decision to place him on precautionary suspension. The applicant was suspended without pay after being charged with misconduct. He referred the dispute over his suspension to the Safety \& Security Sectorial Bargaining Council. After several postponements at his request the presiding officer ordered that he be suspended without pay. He then made an urgent application in the Labour Court. The Labour Court dismissed the application on the basis that it lacked jurisdiction to intervene in incomplete disciplinary proceedings.

The disciplinary hearing resumed and he was dismissed. The arbitrator subsequently reinstated him. The employer took the award on appeal, and the Labour Appeal Court ruled that the Labour Court has the power to restrain the employer from continuing with a disciplinary hearing against an employee, but only in cases where grave injustice would result if the Labour Court does not interfere. The matter was therefore referred back to the Labour Court to decide issues that were outstanding.

There is however an interesting precedent that the Booysen judgment has brought with regard to the basis on which a suspended employee can approach the Labour Court, which is the unfairness of the proceedings or unfairness of the conduct by the employer towards the employee. To this end, Venter (2011) notes that:

\begin{abstract}
"The judgement has far reaching consequences for employers in that the Labour Court can now intervene in an employer's internal disciplinary proceedings. An employee who is being subjected to a disciplinary process and who feels that the proceedings are unfair or that the employer's conduct towards him/her in the disciplinary proceedings is unfair may now approach the Labour Court for an order interdicting unfair conduct, which includes the disciplinary action itself."
\end{abstract}

The employee has a right to approach the Labour Court by way of an application. However, there are requirements which must be met before an application by an employee can be entertained by the court on the basis of urgency as laid down in the case of Lebu v Maquasi Hills Local Municipality \& others (2012] 4 BLLR 411 (LC)), where the applicant as the municipal manager was placed on precautionary suspension without having been given the opportunity to respond as required by Regulation 6 of the Local Government : Disciplinary Regulations for Senior Managers, 2010 which states that a senior manager must be given at least seven(7) days to respond to the notice to suspend:

- Applicant must make out a case for urgent relief on the papers in sufficient particularity,

- The affidavit must contain the reasons for urgency and why urgent relief is necessary,

- The reasons why the requirements of the rules were not complied with.

In the case of Masemola the court said this about urgency as a requirement to apply for relief in the Labour Court: "Rule 8(2) of the Rules of the Labour Court provides that:

"The affidavit in support of the application must also contain- The reasons for urgency and why urgent relief is necessary; The reasons why the requirements of the rules were not complied with, if that is the case."

\section{Conclusion}

The LRA prohibits unfair suspension of the employee by the employer. The PSCBC Resolution 1 of 2003 provides for SMS Handbook which is a disciplinary code that deals with misconduct and disciplinary matters which concern senior employees in the Public Service. The SMS Handbook states the circumstances under which an employee can be placed under precautionary suspension, and case law developed to an extent of setting down pre-suspension procedures that must be followed.

An employee should only be placed on precautionary suspension for a fair reason based on the requirements set 
out in the regulations.

There are however cases in which the employers are vindicated by the courts in their quest to maintain discipline in the workplace. It is also important to understand that the courts and the tribunals are not saying that employees should not be disciplined but that in imposing discipline the right procedures and the right processes must be followed to the end. If an employee has to be placed on precautionary suspension, that must be done fairly by following the right processes.

\section{Recommendations}

The people in authority at the workplace who are to deal with labour relations issues are supposed to be trained extensively and capacitated so that they can have the necessary skills to handle issues of suspensions in order to know when it will be appropriate to suspend or not. In order not to be found wanting, the employers should be weary and exercise restraint in suspensions arising from misconduct. The principle that requires the other side should be heard should always be applied in the disciplinary dealings between the employer and the employee at all times in order to ascertain whether to suspend or not before disciplinary hearing commences.

\section{References}

Biggs L, Van der Walt 2011. Aspects of unfair suspension at work' Obiter 32(3):704-781.

Conradie M, Deacon J 2009. To suspend or not to suspend' Journal for Judicial Science, 34(1): 46-56.

Duffy DP, Hostetler B 2013. selected ethics and professionalism issues labor and employment lawyers. From http://www.nationalemploymentlawcouncil.org/finaldownload/downloadid-

nonmember/agenda_pdfs/2013/selected_ethics_and_professionalism_issues_labor_and_employment_lawyers.pdf. (Retrieved November 10, 2013).

Gaibie S 2012. Interdicting suspension and the disciplinary enquiry: The role of the Labour Court' presented at the $25^{\text {th }}$ Annual Labour Law Conference (2012) at Sandton Convention Centre, South Africa.

Grogan J 2007. Dismissal, Discrimination \& Unfair Labour Practices pp. 71-72.

Kabir A 2013. Law is not a dry subject, it's not static, it's dynamic. From http://deshgujarat.com/2013/01/19/law-is-not-a-dry-subject-itsnot-static-its-dynamiccji-altamas-kabir/. (Retrieved November 18, 2013).

Le Roux L 2012. The new unfair labour practice, ActaJuridica, p. 41.

LGCADP 2010. The Local Government Disciplinary Code and Procedures. From http://d2zmx6mlqh7g3a.cloudfront.net Icdn/farfuture/pufbefemlgtgjjlo3bia4a2muliboahxpe6ggtxzrd8/mtime:1381178512/files/gazettes/091127localdisciplinarycodeforsenior\%20mgt.pdf. (Retrieved November 1, 2013).

McGregor M, Budeli M 2010. Labour Law, Annual Survey of South African Law, p. 799.

Neville R, Hayes M 2009. Employment Law Issues in Leading Change. From http://imca.ie/assets/files/management\%20themes lemployment\%20law\%20issues\%20in\%20leading\%20change.pdf. (Retrieved April 6, 2013).

PSC, 2011. Public Service Commission, Report on Management of Precautionary Suspension in the Public Service. From http://www.psc.gov.za/documents.precautionary ysuspension.pdf. (Retrieved March 7, 2013).

Rheeder J 2013. How to suspend employees? From http://www.jrattorneys.co.za/south-african-labour-law-case-articles/disciplinaryhearings/26-suspension-friend-or-foe.html. (Rretrieved November 4, 2013).

Smit N, Mpedi L 2012. An update on Labour Law, developments from the South African courts: May 2010- February 2012' (2012) TSAR 522, 528. From http://www.sabinet.co.za/abstracts/ju_tsarjju_tsar_2012_n3_a8.html. (Retrieved October 22, 2013.

Venter D 2011. Interfering in disciplinary hearings, Without Prejudice, 47: 49-58. 